\title{
Cytogenetic Studies on Some Kashmir Grasses. VIII Tribe Agrostideae, Festuceae and Paniceae
}

\author{
Kuldeep Kumar Koul ${ }^{1}$ and R. N. Gohil \\ Department of Botany, University of Kashmir, Srinagar-190006, India
}

Accepted April 18, 1991

The present work is in continuation with the cytogenetic studies carried out on the fodder grasses of Jammu and Kashmir Himalayas (Gohil and Koul 1988a, 1988b, Koul 1990, Koul and Gohil 1989, 1990). Presently 33 species belonging to three tribes Agrostideae, Festuceae and Paniceae have been studied. The present communication puts on record the details of meiosis observed in these taxa.

\section{Materials and method}

For the detailed meiotic studies methods employed earlier (Gohil and Koul 1988a) have been followed. Table 1 lists the species studied alongwith their places of collection and voucher numbers under which they have been accessioned. The voucher specimens have been deposited in Kashmir University Herbarium (KASH).

\section{Observations}

The present work is based on 33 species belonging to 3 tribes Agrostideae (16 species), Festuceae ( 7 species) and Paniceae (10 species). While the salient features of normal meiosis, observed in 27 species, are given in Table 2, details of reduction division in species exhibiting abnormal meiosis are described separately.

\section{Agrostis gigantea:}

Chromosomal pairing in this species with $n=21$ was normal and only bivalents were discernible at diplotene and metaphase-I. The chiasmata frequency per cell and per bivalent determined at diplotene was found to be $38 \pm 0.87$ and 1.80 and in cells at metaphase-I it was found to be $36.77 \pm 1.12$ and 1.75 per cell per bivalent respectively. Meiotic studies in this species, however, revealed the presence of chromatin positive connections between some bivalents in cells at diakinesis (Fig. 3). These connections were more prominent between bivalents that were closer to each other. The presence of these connections did not effect the future course of meiosis and anaphase-I segregation was normal with 21 chromosomes going to each pole. $83 \%$ of the pollen produced by this species was found to be stainable.

\section{Agrostis munroana:}

Meiosis in this species, which had $n=21$, was characterised by the presence of quadrivalents in 6 out of the 23 cells scored at diakinesis. While in 5 cells a single quadrivalent per cell was observed, in one of the cells 2 quadrivalents were present (Fig. 5). In all the 42 cells secored at metaphase-I, 21 bivalents only were observed (Fig. 6). The chiasmata frequency at diakinesis was found to be $41 \pm 0.76$ and 1.95 per cell and per bivalent respectively. The anaphase-I disjunction pattern was also irregular. Lagging chromosomes $(0-2$ per cell) were clearly visible

\footnotetext{
${ }_{1}$ Present address-Department of Botany, University of Delhi, Delhi-110007, India.
} 
in 23 of the 67 cells scored at anaphase-I. While $56 \%$ of the pollent produced by this plant stained well, $34 \%$ microspores had micronuclei.

The present count of $\mathrm{n}=21$ is new for $A$. munroana.

Table 1. List of species studied during the present investigation

\begin{tabular}{|c|c|c|c|}
\hline Taxa & $\begin{array}{l}\text { Place of } \\
\text { collection }\end{array}$ & $\begin{array}{l}\text { Altitude } \\
(\mathrm{m})\end{array}$ & $\begin{array}{l}\text { Accession Number } \\
\text { KU/CY. L. H./KK }\end{array}$ \\
\hline \multicolumn{4}{|l|}{ Tribe Agrostideae } \\
\hline Agrostis gigantea Roth & Khillanmarg & 3,000 & 102 \\
\hline A. hissarica (Rozhev.) Bor & Chandilora & 2,100 & 118 \\
\hline A. munroana Aitch. and Hems. & Khillanmarg & 3,000 & 2 \\
\hline A. pilosula Trin. & Anchar lake & 1,550 & 52 \\
\hline A. stolonifera Linn. & Drass & 3,249 & 3 \\
\hline Alopecurus arundinaceus Poir. & Apharwat & 3,400 & 30 \\
\hline Calamagrostis epijegos (Linn.) Roth & Panamic & 3,234 & 8 \\
\hline $\begin{array}{l}\text { C. pseudophragmites Var. tartarica } \\
\text { (Hook. f.) Bor }\end{array}$ & Leh & 3,550 & 9 \\
\hline C. pseudophragmites (Hook. F.) Bor & Tangmarg & 2,150 & 116 \\
\hline C. stoliczkai Hook. F. & Abran & 3,500 & 26 \\
\hline Phleum paniculatum Huds. & Parimahal & 1,650 & 95 \\
\hline P. pratense Linn. & Hazratbal & 1,550 & 27 \\
\hline P. himalaicum Mez. & Shankracharya & 1,650 & 39 \\
\hline Polypogon fugax Nees & Hazratbal & 1,550 & 17 \\
\hline P. monspeliensis (Linn.) Desf. & Anchar lake & 1,550 & 46 \\
\hline P. viridis (Gouan) Breistr & Anchar lake & 1,550 & 27 \\
\hline \multicolumn{4}{|l|}{ Tribe Festuceae } \\
\hline Dactylis glomerata Linn. & Tangmarg & 2,150 & 5 \\
\hline Festuca arundinacea Scherb. & Khillanmarg & 3,000 & 128 \\
\hline F. valesiaca Schleich. ex. Gaud. & Parimahal & 1,650 & 1 \\
\hline Lolium temulentum Linn. & Hazratbal & 1,550 & 12 \\
\hline Selerochloa dura (Linn.) P. Beauv & Hazratbal & 1,550 & 23 \\
\hline Poa pratensis Linn. & Ferozpur Nallah & 2,100 & 18 \\
\hline P. trivialis Linn. & Baramullah & 1,400 & 114 \\
\hline \multicolumn{4}{|l|}{ Tribe Paniceae } \\
\hline Brachiaria eruciformis (J. E. Sm.) Stapf & Hazratbal & 1,550 & 5 \\
\hline $\begin{array}{l}\text { Digitaria cruciata (Nees ex steud.) } \\
\quad \text { A. Camus }\end{array}$ & Hazratbal & 1,550 & 123 \\
\hline D. sanguinalis (Linn.) Scop & Harwan & 1,550 & 10 \\
\hline D. violascens Link. & Anchar lake & 1,550 & 115 \\
\hline Echinochloa colonum Linn. & Harwan & 1,600 & 130 \\
\hline E. crus-galli (Linn.) P. Beauv. & Anchar lake & 1,550 & 13 \\
\hline Panicum antidotale Retz. & Canal Road Jammu & 525 & 21 \\
\hline Pennisetum flaccidum Griseb. & Hunder & 3,018 & 34 \\
\hline P. orientale L. C. Rich. & Shankracharya & 1,650 & 111 \\
\hline Setaria viridis (Linn.) P. Beauv. & Hazratbal & 1,550 & 44 \\
\hline
\end{tabular}

\section{Calamagrostis pseudophragmites:}

Meiosis in this taxon which had $n=14$ was characterized by the presence of

i) Chromation positive connections between bivalents at diplotene (Fig. 11),

ii) some univalents at metaphase-I, and

iii) the tendency of chromosomes to remain clumped both at metaphase-I and anaphase-I (Fig. 12). On account of the last abnormality the chromosomal segregation was irregular to the two poles. These anomalies later got reflected in a decreased pollen stainability which was only $58 \%$ for this species. 
Polypogon monspeliensis:

In this species although 21 bivalents were invariably observed in cells at diplotene, in 3 cells a single quadrivalent each was also observed in addition to 19 bivalents (Fig. 16). In cells at

Table 2. Salient features of reduction division in 27 species of tribes Agrostideae, Festuceae and Paniceae undergoing normal meiosis

\begin{tabular}{|c|c|c|c|c|c|}
\hline \multirow[t]{2}{*}{ Taxa } & \multirow{2}{*}{$\begin{array}{l}\text { Fig. } \\
\text { Nos. }\end{array}$} & \multirow{2}{*}{$\begin{array}{l}\text { No. of } \\
\text { nucleolar } \\
\text { bivalent } / \mathrm{s}\end{array}$} & \multicolumn{2}{|c|}{$\begin{array}{c}\text { Chiasmata frequency } \pm S D \\
\text { per cell/per bivalent }\end{array}$} & \multirow{2}{*}{$\begin{array}{l}\text { Pollen } \\
\text { staina- } \\
\text { bility }\end{array}$} \\
\hline & & & Diplotene & Metaphase-I & \\
\hline \multicolumn{6}{|l|}{ Tribe Agrostideae: } \\
\hline Agrostis stolonifera $(\mathrm{n}=\mathbf{2 1})$ & 1 & 45 & $41.8 \pm 0.4 / 1.98$ & - & $96 \%$ \\
\hline A. hissarica $(\mathrm{n}=21)$ & 4 & $3-4$ & $41.6 \pm 0.48 / 1.98$ & - & $98 \%$ \\
\hline A. pilosula $(\mathrm{n}=21)$ & 7 & 3 & $44.14 \pm 0.83 / 2.10$ & $41.8 \pm 0.8 / 1.98$ & $98 \%$ \\
\hline Alopecurus arundinaceus $(\mathrm{n}=14)$ & 2 & - & $26.6 \pm 0.48 / 1.89$ & $16.75 \pm 0.82 / 1.19$ & $98 \%$ \\
\hline Calamagrostis epigejos $(\mathrm{n}=14)$ & 8,9 & $2-3$ & $27.25 \pm 0.43 / 1.94$ & $22.2 \pm 0.4 / 1.58$ & $97 \%$ \\
\hline $\begin{array}{l}\text { C. pseudophragmites var. } \\
\text { tartarica }(\mathrm{n}=14)\end{array}$ & 10 & $4-5$ & $26.5 \pm 0.95 / 1.88$ & $21.12 \pm 0.78 / 1.50$ & $98 \%$ \\
\hline${ }^{* * *}$ C. stoliczkai $(\mathrm{n}=14)$ & 13 & - & $29.12 \pm 0.92 / 2.07$ & $25.0 \pm 0.49 / 1.81$ & $95 \%$ \\
\hline Phleum paniculatum $(\mathrm{n}=14)$ & 14 & $0-1$ & $33.0 \pm 1.15 / 2.35$ & $20.99 \pm 1.46 / 1.49$ & $95 \%$ \\
\hline$P$. pratense $(\mathrm{n}=14)$ & 15 & 1 & $30.11 \pm 0.87 / 2.15$ & $27.0 \pm 0.85 / 1.92$ & $93 \%$ \\
\hline${ }^{* * P}$. himalaicum $(\mathrm{n}=28)$ & 17 & 4 & - & - & $97 \%$ \\
\hline Polypogon fugax $(\mathrm{n}=21)$ & 18 & 3 & $44.5 \pm 0.76 / 2.10$ & $40.2 \pm 0.74 / 1.91$ & $98 \%$ \\
\hline$* * * P$. viridis $(\mathrm{n}=14)$ & 20 & $2-3$ & $25.46 \pm 0.92 / 1.81$ & $21.12 \pm 0.78 / 1.50$ & $96 \%$ \\
\hline \multicolumn{6}{|l|}{ Tribe Festuceae: } \\
\hline Dactylis glomerata $(\mathrm{n}=7)$ & 21 & $1-2$ & $11.71 \pm 0.45 / 1.67$ & $10.14 \pm 0.34 / 1.44$ & $99 \%$ \\
\hline Festuca arundinacea $(\mathrm{n}=21)$ & 22 & - & - & $20.85 \pm 0.45 / 0.99$ & $100 \%$ \\
\hline$F$. valesiaca $(\mathrm{n}=21)$ & 23 & 2 & $30 \pm 0.63 / 1.42$ & $26.6 \pm 1.2 / 1.26$ & $93 \%$ \\
\hline Lolium temulentum $(\mathrm{n}=7)$ & 24 & 2 & $15.28 \pm 0.78 / 2.18$ & $10.77 \pm 0.56 / 1.53$ & $97 \%$ \\
\hline Poa pratensis $(\mathrm{n}=7)$ & 26 & 1 & $12 \pm 0.32 / 1.7$ & $8.3 \pm 0.51 / 1.2$ & $98 \%$ \\
\hline$P$. trivialis $(\mathrm{n}=7)$ & 27 & 2 & $8.33 \pm 0.47 / 1.18$ & $7.6 \pm 0.48 / 1.07$ & $100 \%$ \\
\hline Sclerochloa dura $(\mathrm{n}=7)$ & 25 & 2 & $15 \pm 0 / 2.14$ & $11.7 \pm 0.48 / 1.66$ & $98 \%$ \\
\hline \multicolumn{6}{|l|}{ Tribe Paniceae: } \\
\hline${ }^{*}$ Brachiaria eruciformis $(\mathrm{n}=9)$ & 28 & 1 & - & - & $89 \%$ \\
\hline \multirow[t]{2}{*}{${ }^{* *}$ Digitaria cruciata $(\mathrm{n}=18)$} & 29 & $1-2$ & $35.85 \pm 0.34$ & $24.75 \pm 0.43$ & $83 \%$ \\
\hline & & & 1.9 & 1.37 & \\
\hline \multirow[t]{2}{*}{ D. sanguinalis $(\mathrm{n}=36)$} & 30 & $3-6$ & $\underline{73.57 \pm 1.04}$ & $68 \pm 1.11$ & $68 \%$ \\
\hline & & & 2.04 & 1.88 & \\
\hline${ }^{*}$ Echinochloa colonum $(\mathrm{n}=27)$ & 32 & $2-4$ & - & - & $79 \%$ \\
\hline${ }^{*} E$. crus-galli $(\mathrm{n}=27)$ & 33 & $3-4$ & - & - & $94 \%$ \\
\hline \multirow[t]{2}{*}{ Panicum antidotale $(\mathrm{n}=9)$} & 34 & 1 & $11.5 \pm 0.5$ & $\underline{7.14 \pm 0.63}$ & $99 \%$ \\
\hline & & & 1.27 & 0.79 & \\
\hline \multirow[t]{2}{*}{ Pennisetum flaccidum $(\mathrm{n}=9)$} & 35 & 1 & $15.03 \pm 0.78$ & $14.18 \pm 0.63$ & $98 \%$ \\
\hline & & & 2.03 & 1.70 & \\
\hline \multirow[t]{2}{*}{ Setaria viridis $(\mathrm{n}=9)$} & 39 & 1 & $15.62 \pm 0.99$ & $14.1 \pm 0.44$ & $91 \%$ \\
\hline & & & 1.73 & 1.57 & \\
\hline
\end{tabular}

* Due to the paucity of enough material the chiasmata frequency could not be studied.

** New counts.

*** First report.

metaphase-I 21 bivalents only were seen (Fig. 19) and this was followed by normal disjunction of 21 chromosomes to each pole at anaphase-I. The chiasmata frequency calculated per cell and per bivalent at diplotene was $43.5 \pm 1.20$ and 2.06 and in cells at metaphase-I it was $41.23 \pm$. 0.973 and 1.95 respectively. Pollen stainability was very low i.e. $18 \%$ in this species. 


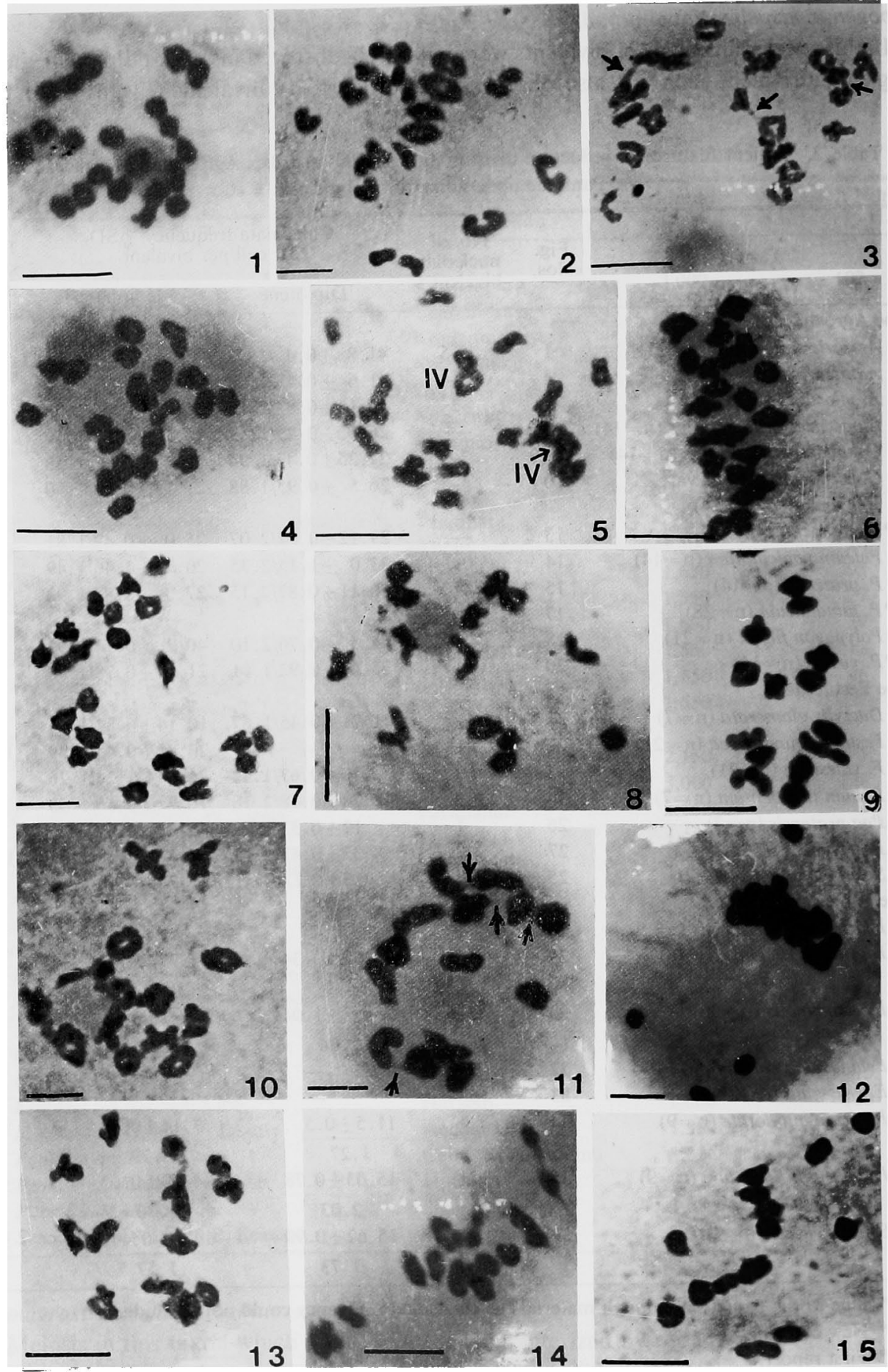

Figs. 1-39. Some stages of meiosis in 33 species of tribes Agrostideae, Festuceae and Paniceae.

1) diplotene in Agrostis stolonifera showing 21 bivalents.

2) metaphase-I in Alopecurus arundinaceus showing $9 \mathrm{II}+10 \mathrm{I}$.

3) diakinesis in Agrostis gigantea $(\mathrm{n}=21)$ showing interbivalentary connections (arrows).

4) diakinesis in $A$. hissarica with 21 bivalents.

5) diakinesis in $A$. munroana showing 2 IV +17 II.

6) metaphase in $A$. munroana showing 21 bivalents.

7) diakinesis in $A$. pilosula showing 21 bivalents. 

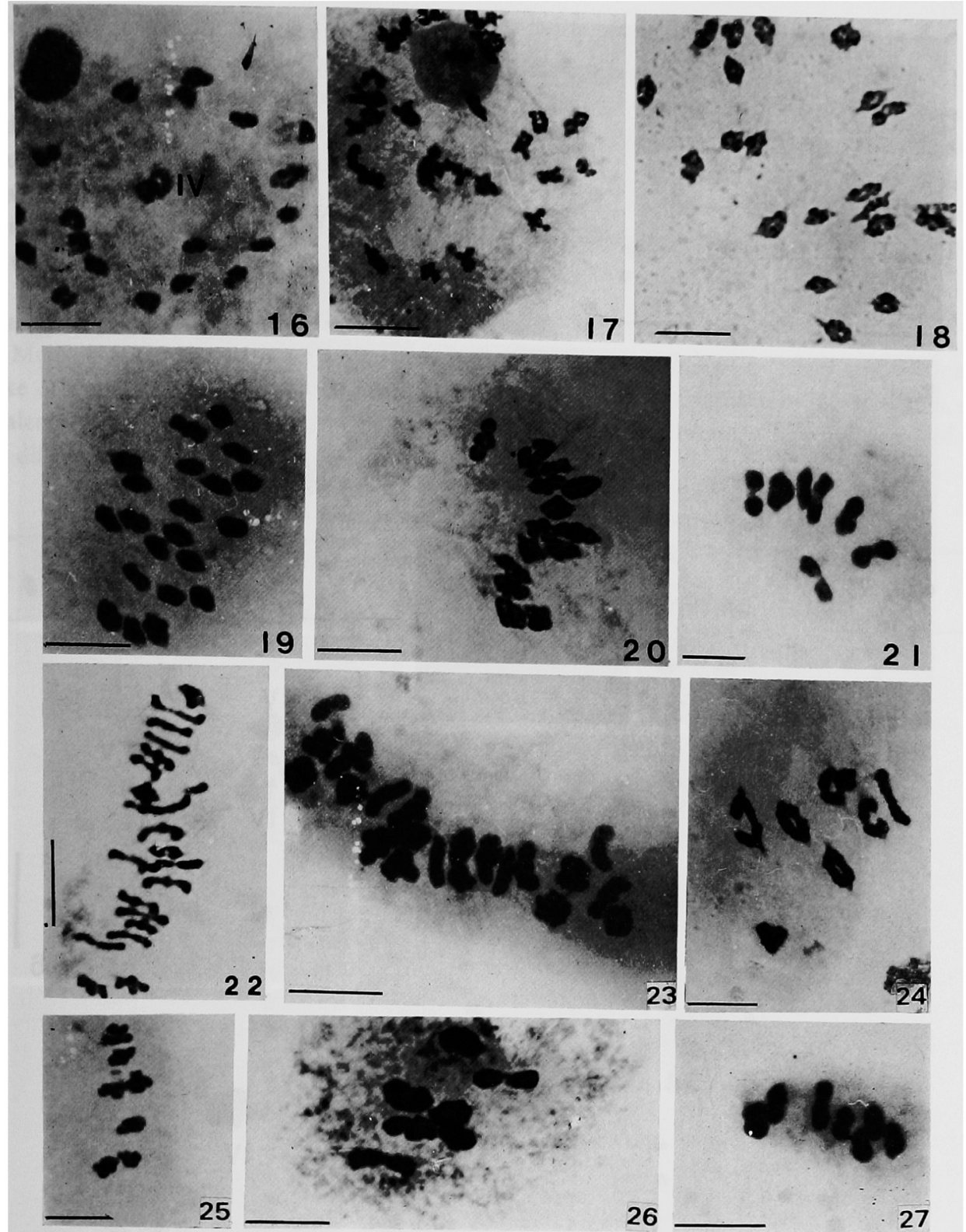

16) diakinesis in Polypogon monspeliensis showing 1 IV +19 II.

17) diplotene in Phleum himalaicm showing 28 bivalents.

18 ) and 19) metaphase-I in Polypogon fugax and P. monspeliens is showing 21 bivalents each.

20) metaphase-I in $P$. viridis showing 14 bivalents.

21) metaphase-I in $P$. viridis showing 14 bivalents.

21) metaphase-I in Dactylis glomerata showing 7 bivalents.

22 and 23) metaphase-I in Festuca arundinacea and $F$. valesiaca showing 21 bivalents each.

24,25,26 and 27) metaphase-I in Lolium temulentum (24) Sclerochloa dura (25), Poa pratensis (26) and Poa trivialis (27) showing 7 bivalents each. (Scale $=10 \mu \mathrm{m})$

8) and 9) diplotene and metaphase-I in Calamagrostis epigejos showing 21 bivalents each.

10) diakinesis in $C$. pseudophragmites var. tartarica showing 21 bivalents.

11) diakinesis in C. pseudophragmites $(\mathrm{n}=14)$ showing interbivalent connections (arrows).

12) metaphase-I in C.pseudophragmites showing clumping of chromosomes.

13) diakinesis in C. stoliczkai showing 14 bivalents.

14 and 15) metaphase-I in Phleum paniculatum and $P$. pratense showing 14 bivalents each. (scale $=$ $10 \mu \mathrm{m})$ 


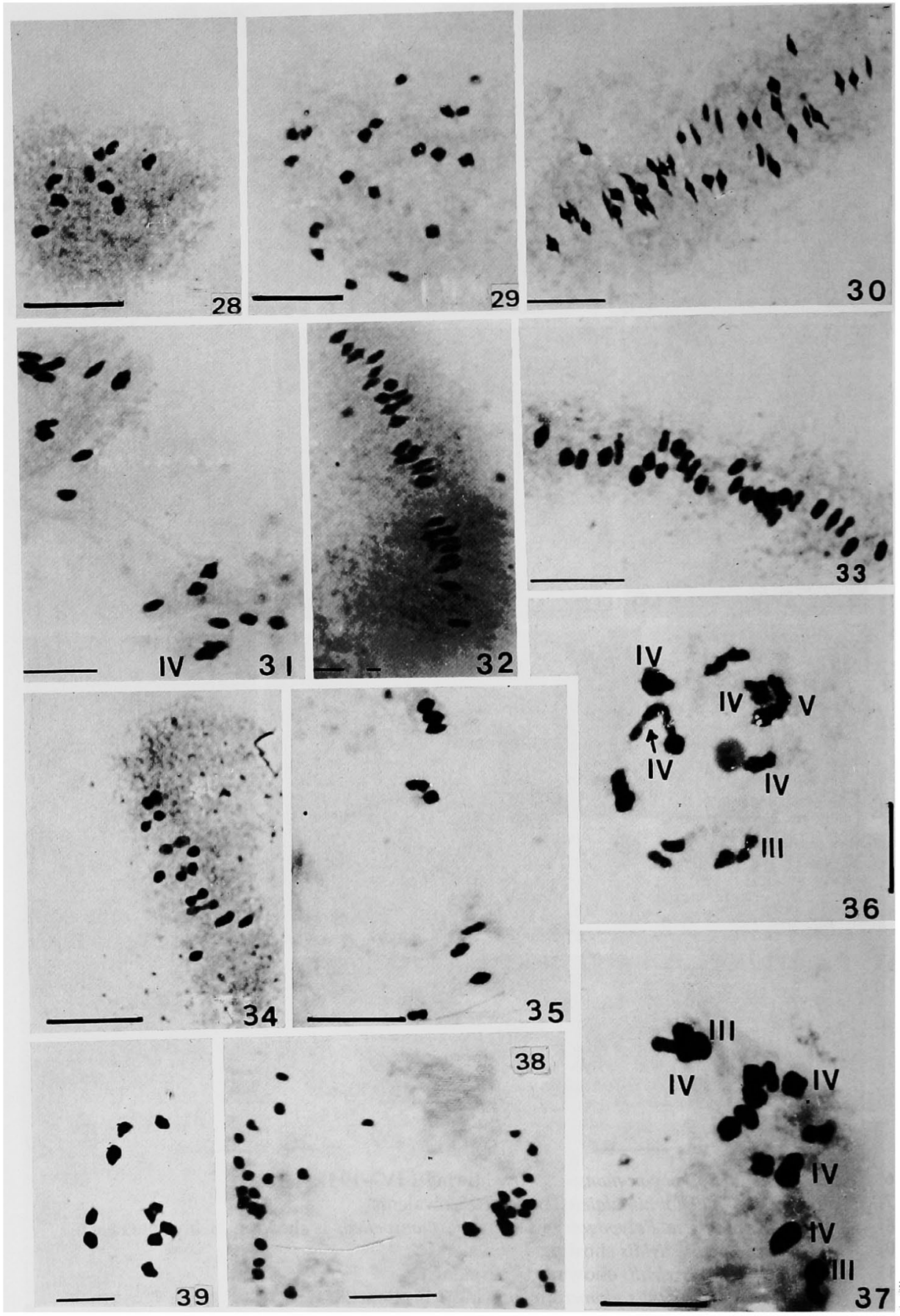

28) diakinesis in Brachiaria eruciformis showing 9 bivalents.

29) diakinesis in Digitaria cruciata showing 18 bivalents.

30) metaphase-I in $D$. sanguinalis showing 36 bivalents.

31) metaphase-I in $D$. violascens showing 1 IV +16 II.

32 and 33) metaphase-I in Echinochloa colonum and E. crus-galli showing 27 bivalents each.

34 and 35) metaphase-I in Panicum antidotale and Pennisetum flaccidum showing 9 bivalents each.

36) diplotene in Pennisetum orientale showing $1 \mathrm{~V}+4$ IV +1 III +5 II +2 I.

37) metaphase-I in $P$. orientale showing 4 IV +2 III +7 II.

38) anaphase-I in $P$. orientale showing segregation of 17:1:18 chromosomes.

39) diakinesis in Setaria viridis showing 9 bivalents. (Scale $=10 \mu \mathrm{m}$ ) 
Digitaria violascens:

Although most of the pollen mother cells studied revealed the presence of regular 18 bivalents at diakinesis and metaphase-I, in $9 \%$ and $4 \%$ cells at diakinesis and metaphase-I a single quadrivalent association was observed in addition to 16 bivalents (Fig. 31). The chiasmata frequency per cell and per bivalent at diakinesis was $35.33 \pm 0.47$ and 1.96 and at metaphase-I it was found to be $33.5 \pm 0.86$ and 1.86 respectively. The anaphase-I segregation could not be studied due to the paucity of enough material. The pollen stainability recorded in this species was $65 \%$.

\section{Pennisetum orientale:}

Meiosis in this species, with $n=18$, collected from Shankracharya $(1,650 \mathrm{~m})$ in Srinagar, unlike other species, was highly abnormal characterized by the presence of pentavalents, quadrivalents and trivalents besides bivalents and univalents at diplotene. The frequency of cells with different chromosomal associations is given in Table 3.

Table 3. Chromosomal configurations in Pennisetum orientale.

\begin{tabular}{|c|c|c|c|c|c|}
\hline \multicolumn{5}{|c|}{ Chromosomal associations } & \multirow{2}{*}{ No. of cells } \\
\hline $\mathrm{V}$ & IV & III & II & I & \\
\hline \multicolumn{6}{|l|}{ Diplotene } \\
\hline 1 & 4 & 1 & 5 & 2 & 2 \\
\hline 1 & 1 & 1 & 12 & - & 1 \\
\hline 1 & - & 3 & 11 & - & 3 \\
\hline- & 4 & - & 10 & - & 2 \\
\hline - & 3 & - & 12 & - & 11 \\
\hline- & 2 & 2 & 11 & - & 2 \\
\hline - & 2 & - & 14 & - & 6 \\
\hline \multicolumn{6}{|c|}{ Metaphase-I } \\
\hline- & 4 & 1 & 8 & 1 & 2 \\
\hline - & 4 & - & 10 & - & 2 \\
\hline- & 3 & 2 & 9 & - & 3 \\
\hline 一 & 3 & 1 & 10 & 1 & 3 \\
\hline - & 3 & - & 12 & - & 2 \\
\hline- & 2 & 2 & 11 & - & 2 \\
\hline- & 2 & 1 & 12 & 1 & 3 \\
\hline- & 2 & 1 & 11 & 3 & 2 \\
\hline- & 2 & - & 14 & - & 6 \\
\hline- & 2 & 一 & 12 & 4 & 2 \\
\hline- & 1 & 3 & 11 & 1 & 1 \\
\hline- & 1 & 2 & 13 & - & 2 \\
\hline- & 1 & 1 & 14 & 1 & 2 \\
\hline- & 1 & - & 14 & 4 & 9 \\
\hline- & - & 2 & 15 & - & 1 \\
\hline- & - & 1 & 16 & 1 & 1 \\
\hline- & - & 1 & 8 & 17 & 1 \\
\hline
\end{tabular}

As is clear from Table 3 , in all the 27 cells studied at diplotene multivalent associations were always present. While the pentavalents ( 1 per cell) were seen in 6 cells, quadrivalents existed in 24 of the 27 cells scored (Fig. 36). The number of quadrivalents per cell ranged from 1-4. Trivalents ranging in number from 1-3 were also seen in these cells. The number of bivalents per cell ranged from $5-14$.

In cells at metaphase-I the frequency of multivalent associations decreased and was accompanied by an increase in the number of bivalents. In none of the 44 metaphase-I cells scored were pentavalents or any other higher configurations observed. Trivalents ranging in number 
from 1-3 per cell were observed in 21 cells at this stage (Fig. 37) and bivalents and univalents ranged from 8-16 and 1-17 per cell respectively. While the chiasmata frequency per cell per bivalent at diplotene was found to be $30.75 \pm 1.08$ and 1.69 , at metaphase-I it was found to be $29 \pm 0.70$ and 1.61 respectively.

The meiotic anomalies upset anaphase-I disjunction where $98 \%$ cells had 18:1:17 segregation (Fig. 38). In the remaining $2 \%$ cells, although the number of chromosomes at the two poles could not be counted, 2-8 lagging chromosomes were clearly visible. Despite such a high number of lagging chromosomes at anaphase-I, a maximum of 4 micronuclei were observed at telophase-I stage. The frequency of cells having different number of micronuclei at telophase-I is presented in Table 4.

As a result of all these abnormalities, $79 \%$ pollen grains produced by this species were shrunken and remained unstained.

Table 4. Frequency of telophase-I cells with different number of micronuclei in Pennisetum orientale

\begin{tabular}{lccccc}
\hline \hline $\begin{array}{l}\text { No. of } \\
\text { micronuclei }\end{array}$ & 0 & 1 & 2 & 3 & 4 \\
\hline $\begin{array}{l}\text { No. of cells } \\
\text { Parcentage }\end{array}$ & 19 & 18 & 12 & 9 & 1 \\
\hline
\end{tabular}

\section{Discussion}

During the present course of investigations 33 species belonging to three different tribes viz. Agrostideae (16 species), Festuceae (7 species) and Paniceae (10 species) were studied. While new chromosome counts have been recorded in species namely Agrostis munroana $(\mathrm{n}=21)$, Phleum himalaicum $(\mathrm{n}=28)$ and Digitaria cruciata $(\mathrm{n}=18)$, cytology of Calamagrostis stoliczkai $(\mathrm{n}=14)$ and Polypogon viridis $(\mathrm{n}=14)$ has been studied for the first time. The 33 species studied exist in as many cytotypes. Out of these $27 \%$ are diploids and the remaining $73 \%$ are polyploids. This is in conformity with the contention that polyploidy is quite prevalent in this group (Stebbins 1956, Mehra et al. 1968 and Bir et al. 1987). Information available on the cytogenetics of grasses reveal that for species like Sclerochloa dura $(\mathrm{n}=7)$, Pennisetum flaccidum $(\mathrm{n}=9)$ and Setaria viridis $(\mathrm{n}=9)$ only the diploid cytotypes had been reported earlier (Fedorov 1969) and these numbers have been confirmed during the present work. These observations point towards the highly conservative nature of these species as far as numerical changes in their chromosomes are concerned.

Base numbers:

In the taxa studied presently 2 base numbers ( $x=7$ and 9) have been observed. While in the members of the tribes Agrostideae and Festuceae base number 7 has been recorded, in Paniceae base number 9 has been observed. According to Darlington and wylie (1955) Agrostideae is dibasic $(x=5,7)$ and both Festuceae and Paniceae are heptabasic with base numbers ranging from 5 to 19. Since then (Darlington and Wylie 1955) more information has accumulated and the present situation regarding the base numbers in these three tribes is given in Table 5 .

Situation regarding base numbers in the family Poaceae is very interesting because earlier workers have recorded upto 17 base numbers ranging from $x=2$ to 23 in different taxa of this family (Fig. 40). Keeping in view Stebbins (1971) contention that taxa having $x=12$ are of polyploid origin and all the higher numbers should be considered as secondary base numbers, in the family poaceae only ten ( $x=2$ to 11$)$ base numbers can be recognized.

The above information points towards the fact that in this family polyploidy accompanied 
by aneuploid loss or gain of chromosomes has been of great help in evolution. It would not be out of place to mention here that in Poaceae earlier to the finding of $2 n=4$ in Zingeria biebersteiniana (Tsevelev and Zhukova 1974), the lowest chromosome number $2 n=6$ was recorded by Rao (1962) in Iseilema anthephoroides.

Like the family as a whole a number of genera of this assemblage are also polybasic. It also holds good for the genera included in the present study (Table 6).

A perusal of the Table 6 reveals that although eight genera included in the present study are reported to have two or more than two base numbers, all the genera studied during the present investigations have a single base number each. Although Darlington and Wylie (1955), Fedorov (1969) and Bir et al. (1987) have reported the presence of only a single base number $(\mathrm{x}=9)$ in Echinochloa, the report of $2 \mathrm{n}=12$ and 24 in E. colonum by Mehra et al. (1968) points

Table 5. Base numbers in tribes Agrostideae, Festuceae and Paniceae

\begin{tabular}{llcl}
\hline \multirow{2}{*}{ Authority } & \multicolumn{2}{c}{ Base numbers recognized in the three tribes } \\
\cline { 2 - 4 } & \multicolumn{1}{c}{ Agrostideae } & \multicolumn{1}{c}{ Festuceae } & \multicolumn{1}{c}{ Paniceae } \\
\hline $\begin{array}{l}\text { Darlington and Wylie } \\
\text { (1955) }\end{array}$ & $2(5,7)$ & $7(5,6,7,8,9,11,13)$ & $7(7,9,10,12,15,17$, \\
Bor (1960) & $1(7)$ & $2(5,7)$ & $19)$ \\
Fedorov (1969) & $5(4,5,7,9,10)$ & $3(5,7,10)$ & $6(7,9,10,15,17,19)$ \\
Present Position & $5(4,5,7,9,10)$ & $3(5,7,10)$ & $7(5,7,8,9,10,17,19)$ \\
& & & $10(5,6,7,8,9,10,12$, \\
\end{tabular}

towards the presence of a lower base number $(\mathrm{x}=6)$ in this genus. In Pennisetum too, Bir et al. (1987) recognize only two base numbers i.e. $x=9$ and 17 despite the fact that Swaminathan and Nath (1956) had reported $2 \mathrm{n}=10$ and 32 in the somatic cells of Pennisetum ramosum and $P$. massaicum and had suggested the presence of 5 and 8 also as the base numbers. Sharma and De (1956) and Pantulu and Rao (1982) had also reported the presence of $\mathrm{x}=7$ in $P$. orientale and $P$. americanum.

Frequency of taxa with different base

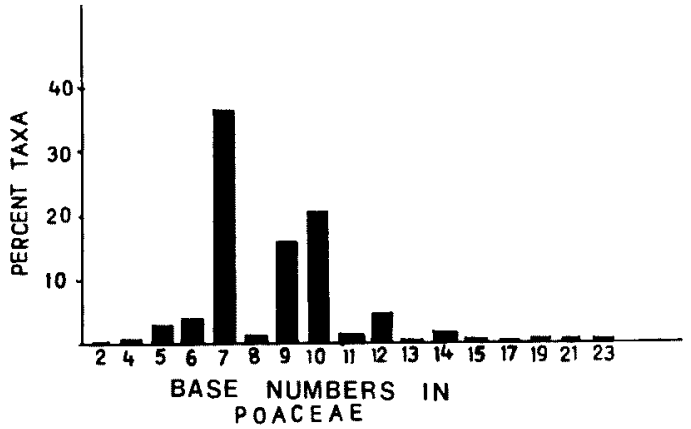

Fig. 40. Range of base numbers in the family Poaceae. numbers reported in the three tribes studied are shown in Fig. 41 A, B, C. As is clear from the figures while in both Agrostideae and Festuceae 7 is the most predominant base number, in the tribe Paniceae, maximum taxa belong to $x=9$. As such these two numbers i.e. $x=7$ and 9 appear to be the primary base number for these tribes and all other might be of secondary origin. One can conclude from Fig. 40 that $x=7$, being the predominant base number in this family, should be taken as the primary base number from which all other numbers have evolved. This conclusion is in conformity with the suggestions made earlier by Wanscher (1934) and Brown (1948). On the basis of studies on plant morphology vis-a-vis primitive and advanced nature of various taxa, some workers like de Wet (1954), Mehra et al. (1968) and Sharma (1979) are of the belief that $x=6$ is the primary base number for this family and all other numbers have evolved from it. This conclusion has been drawn on the basis of the fact that in some of the primitive tribes like Bambuseae, Oryzeae and Phareae, $x=6$ is supposed to be the primary base number from which the secondary base number $(x=12)$ originated as a result of doubling of chromosomes in plants 
with $\mathrm{x}=6$. If this hypothesis is accepted, then on the basis of the frequency of taxa having $x=6$ and/or 12 it appears that both these were not very stable numbers.

While the foregoing discussion seems to support the claim of Wanscher (1934) that $x=7$

Table 6. Different base numbers reported in genera studied during the present work*

\begin{tabular}{|c|c|c|c|}
\hline \multirow{2}{*}{\multicolumn{2}{|c|}{ Taxa }} & \multicolumn{2}{|c|}{ Base numbers } \\
\hline & & Total known & $\begin{array}{l}\text { In Kashmir taxa } \\
\text { (including present work) }\end{array}$ \\
\hline \multirow[t]{6}{*}{ Trobe: } & Agrostideae & & \\
\hline & Agrostis & 4,7 & 7 \\
\hline & Alopecurus & 7 & \\
\hline & Calamagrostis & 7 & \\
\hline & Phleum & 5,7 & 7 \\
\hline & Polypogon & 7 & 7 \\
\hline \multirow[t]{6}{*}{ Tribe: } & Festuceae & & \\
\hline & Dactylis & 7 & 7 \\
\hline & Festuca & 7 & 7 \\
\hline & Lolium & 7 & 7 \\
\hline & Poa & 7 & 7 \\
\hline & Sclerochloa & 7 & 7 \\
\hline \multirow[t]{7}{*}{ Tribe: } & Paniceae & & \\
\hline & Brachiaria & $5,7,8,9,10$ & 9 \\
\hline & Digitaria & $8,9,15,7$ & 9 \\
\hline & Echinochloa & 9,6 & 9 \\
\hline & Panicum & $7,8,9$ & 9 \\
\hline & Pennisetum & $5,7,8,9$ & 9 \\
\hline & Setaria & $9,17,19$ & 9 \\
\hline
\end{tabular}

* Source: Darlington and Wylie (1955), Bor (1960), Fedorov (1969), Mehra and Sunder (1970), Mehra and Remanandan (1973a, b), Mehra and Sharma (1977) and Sharma and Sharma (1979).

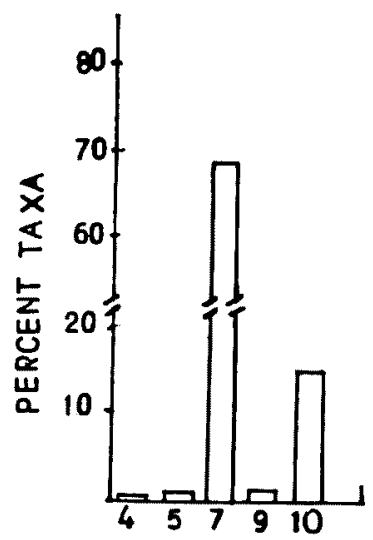

A-AGROSTIDEAE
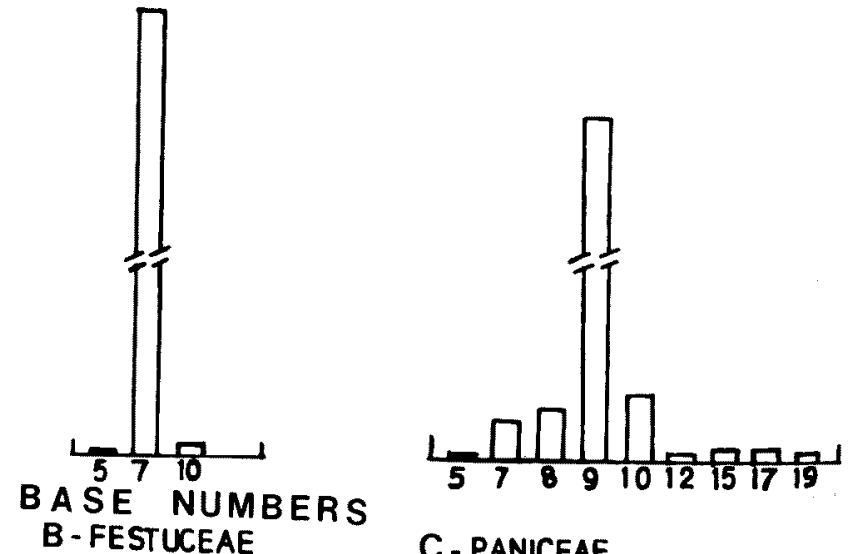

C - PANICEAE

Fig. 41. Range of base numbers in tribes Agrostideae, Festuceae and Paniceae.

is probably the primary base number for this family, it cannot be ignored that Poaceae is of great antiquity and its members existed even in Cretaceous period (Stebbins 1956). In view of this fact it can be assumed that most of the primitive/ancestral taxa of this family which perhaps had $\mathrm{x}=6$ might have perished during the last 127 million years and at present we do 
not have any of the real ancestors of this family with us.

In conclusion, while accepting the hypothesis that $\mathrm{x}=6$ and 12 may be the primary base numbers of this family, it is quite apparant that deviation from these numbers must have taken place long back and tribes like Festuceae, Agrostideae and Paniceae having other base numbers like 7 and 9 in predominance have not only originated at a very early stage but have also established their separate entities. This assumption may also explain the presence of comparatively large sized chromosomes in members of tribe Festuceae, which otherwise is supposed to be quite specialized and thus advanced within the family Poaceae.

\section{Reduction division:}

Very little information is available regarding the chromosome behaviour during reduction division in the species studied in the present investigation. Most of the information available is restricted to the listing of chromosome numbers in the cells of various species studied (Sharma and De 1956, Carnahan and Hill 1961, Chen and Hsu 1961, Patil et al. 1962, Gupta 1963, Nath et al. 1970, Mehra and Sunder 1970, Mehra et al. 1968, Mehra and Remanandan 1973a, b, Khosla and Sharma 1973, Mehra and Sharma 1975a, b, 1977, Katayama and Ikeda 1975, Singh and Gupta 1977, Sharma and Sharma 1979, Bir and Sahni 1987, Bir et al. 1987).

On the basis of ploidy level, type of chromosomal pairing and other abnormalities noticed during reduction division the taxa studied can be grouped into different types and are discussed accordingly.

Diploids with normal chromosomal pairing:

In diploid Lolium temulentum, Poa pratensis, P. trivialis, Sclerochloa dura and Dactylis glomerata all with $\mathrm{x}=7$ and Brachiaria eruciformis, Pennisetum flaccidum, Panicum antidotale and Setaria viridis with $\mathrm{x}=9$, chromosomes paired perfectly and 7/9 bivalents were invariably observed in cells at diplotene and metaphase-I. Although in most of the diploid taxa studied a single bivalent was found attached to the nucleolus in cells at diplotene, occassionally, upto two bivalents were also observed. It indicates that more than one chromosome of their complements might be possessing nucleolar organizing region. No appreciable size difference was observed between the bivalents of any taxa. In all the taxa of tribe Paniceae, however, the bivalents were smaller in size as compared to those of other two tribes. The largest bivalents were observed in the taxa of Festuceae while those of Agrostideae had intermediate size. The chiasmata frequency observed at diplotene ranged from $8.33 \pm 0.47$ (Poa trivialis) to $15.28 \pm$ 0.78 (Lolium temulentum). This variation can be correlated with the size of bivalents in these taxa (Figs. 24 and 27). Despite normal bivalent formation in taxa having smaller chromosomes, some univalents were observed at early/late metaphase-I. This could be due to precocious terminalization of the chiasmata on account of the small size of the bivalents. The anaphase-I segregation in these species was almost normal resulting in more than $90 \%$ pollen stainability.

Prior to the present work, out of the taxa studied by the present worker, some work on reduction division had also been carried out on Alopecurus aequalis (Mehra and Sunder 1970, Mehra and Remanandan 1973a, Mehra and Sharma 1977), Dactylis glomerata (Mehra and Sunder 1970), Pennisetum flaccidum (Mehra and Sunder 1970 and Mehra and Remanandan 1973b), Panicum antidotale (Narayan 1962), Setaria viridis (Mehra and Remandan 1973b and Singh and Gupta 1977) and Lolium temulentum (Bir and Sahni 1987). The present findings are in conformity with the earlier observations. 
Meiosis in polyploids:

Of the 24 polyploids isolated during the present work 10 are tetraploid, 12 hexaploid and 2 octaploid. In polyploids meiotic pairing in conjucture with karyotypic details is considered as a reliable criterion of establishing the type of polyploidy involved. While the presence of multivalent associations reveal genomic homology, their absence indicates that distinctly well differentiated genomes are involved in the origin of the polyploid.

Polyploids with normal meiosis:

Meiosis was perfectly normal in 8 tetraploid taxa (Alopecurus arundinaceus, Calamagrostis pseudophragmites var. tartarica., C. epigejos, C. stoliczkai, Digitaria cruciata, Polypogon viridis, Phleum pratense, P. paniculatum), 8 hexaploids (Agrostis hissarica, A. stolonifera, A. pilosula, Echinochloa colonum, E. crusgalli, Festuca arundinacea, F. valesiaca, Polypogon fugax) and two octaploids (Digitaria sanguinalis and Phleum himalaicum). In all these species bivalents only were observed both at diplotene and metaphase-I stages followed by normal disjunction of chromosomes to the two poles.

Concepts about the type of polyploidy involved have undergone considerable changes since the time when the mere presence or absence of multivalents alone was taken as the criterion of labelling a taxon as an auto- or allopolyploid respectively. Researches conducted on a number of taxa have shown that study of meiosis alone in a polyploid can lead to erroneous conclusions regarding the nature of polyploidy involved because of the following facts:-

i) Autopolyploids of long standing tend to behave like allopolyploids as have been shown in case of Zea mays (Giles and Randolph 1951) and Brassica campestris var. toria (Swaminathan and Sulbha 1959).

ii) Auto or segmental allopolypoids can undergo normal meiosis as a result of the action of some genes which promote homologous pairing only and homoeologous pairing is not allowed. From among the grasses this gene controlled pairing has been observed in Triticum aestivum (Riley and Chapman 1958, Sears and Okamoto 1958, Riley 1960) and Phleum pratense (Müntzing and Prakken 1940).

iii) Chromosomes of a true allopolyploid can undergo interchanges therby upsetting the course of meiosis as a result of the formation of multivalents. Example of structural hybridity superimposed on polyploidy are on record (Gohil 1979, Gohil and Raina 1987, Koul and Gohil 1989).

Because of the above mentioned reasons it is quite clear that to conclude about the type of polyploidy involved in any taxon on the basis of mitotic or meiotic studies alone can lead to erroneous conclusions (Singh et al. 1967, Koul and Gohil 1971). Frequent chromosomal and genic alterations only add to the difficulties in recognizing various types of polyploids. Despite all the limitations in classifying various types of polyploids, on the basis of present observations, polyploids with normal meiosis can, for the time being, be categorized as allopolyploids.

Polyploids with abnormal meiosis:

Abnormal meiosis characterized by the presence of multivalents and other anomalies associated with polyploids having genomic similarities, small or large were observed in hexaploid Polypogon monspeliensis and Agrostis munroana and tetraploid Digitaria violascens and Pennisetum orientale. All these species except $P$. orientale resemble each other in having low frequency of chromsome associations involving four chromosomes only. While in $P$. monspeliensis $1.09 \%$ chromosomes formed quadrivalents, in $D$. violascens and $A$. munroana the frequency of chromsomes forming quadrivalents was $1.19 \%$ and $2.89 \%$ respectively. This type of meiotic behaviour is an indicator of participation of two and three different genomes in the origin of 
the tetraploids and hexaploids, respectively, with only two of the three genomes having small segmental similarities in the hexaploids. All these taxa on the basis of meiotic details can be classified as segmental allopolyploids. The very low frequency of quadrivalents can be taken as an indicator of cryptic structural exchanges superimposed on an allopolyploid nature. At present the tetraploid and the hexaploid species can be assigned the genomic formula as $\mathrm{AAA}^{\prime} \mathrm{A}^{\prime}$ and $\mathrm{AAA}^{\prime} \mathrm{A}^{\prime} \mathrm{BB}$ respectively.

Situation in Pennisetum orientale is quite interesting. Despite being a tetraploid $(2 \mathrm{n}=$ $4 \mathrm{x}=36$ ), associations involving more than four chromsomes (Pentavalents) were observed. The presence of higher associations at the ploidy level where normally associations involving only 4 chromosomes are expected speak of structural interchanges after the polyploid has been formed. The perusal of available literature reveals that Mehra et al. (1968) and Mehra and Remanandan (1973b) have also reported tetraploid cytotypes in this species. While Mehra et al. (1968) have not given the details of meiosis, Mehra and Remanandan (1973b) have reported the presence of associations at diakinesis and metaphase-I. The present finding of complex associations involving upto five chromosomes is the second one. Prior to this associations involving upto eight chromosomes have been reported in the Vaishno Devi population of the same species (Koul and Gohil 1989). Complex associations formed as a result of structural interchanges imposed on polyploidy have also been observed by Gohil (1979) in Allium platyspathum and Gohil and Raina (1987) in Hesperis matronalis. Both these species also happen to be at tetraploid level.

Presence of interbivalent connections in polyploid species:

Chromosomes of two polyploid species, Calamagrostis pseudophragmites (4x) and Agrostis gigantea $(6 \mathrm{x})$ also had bivalents only at diplotene. However, in both these species some faintly stained connections were also observed between bivalents lying close to each other. While subsequent course of meiosis was erratic in C. pseduophragmites characterized by the chromosomes remaining clumped at metaphase and anaphase-I, in $A$. gigantea both metaphase and anaphase-I stages were normal. Pollen stainability too got effected and pollen produced by C. pseudophragmites and A. gigantea showed $58 \%$ and $83 \%$ stainability.

The presence of these interconnections is an interesting feature and has been studied in both plants and mammals (Yunus and Yasmineh 1971, 1972, Stack and Clarke 1973, Klášterská 1978, Klášterská and Ramel 1979, Bir et al. 1987). In grasses the connections have been reported by Godin and Stack (1975) and Bir et al. (1987).

While Yunus and Yasmineh (1971) had attributed these connections to the presence of repetitive DNA, according to Klášterská (1978) these are mere artfacts. Yunus and Yasmineh (1971) proposed that the function of repetitive DNA was to help in the pairing of homologus chromosomes through interchromosomal DNA hybridization. McGill et al. (1974) were of the opinion that such connections can be formed as a result of abnormal condensation in the chromosomes while preparing for divisions. Due to the abnormal condensations these chromosomes get entangled between the loops of other chromosomes and get physically connected by interconnections.

Although it is difficult to assign any of the above reasons in the present case, interbivalentary connections in these two polyploid grass taxa might point towards some cryptic structural similarities in their constituent genomes.

From all the evidence at hand one can safely conclude that speciation and evolution within this family has been possible as the result of increase in the spectrum of variability through changes in base numbers, intra- and interspecific hybridization accompanied by numerical changes in the genomes. In addition to this, besides gene mutations which provide the raw material for recombination, chromosomal rearrangements at all the ploidy levels also seem 
to have been of some help in these processes.

All the above mentioned changes in the generic systems have been ably tolerated by the members of this group as nearly all of them have efficient means of vegetative propagation. This type of propagation ensures the survival of the genetically altered types which otherwise face extinction on account of sexual sterility imposed as a result of these changes.

\section{Summary}

Meiotic studies have been carried out in 33 species belonging to 3 tribes namely Agrostideae, Festuceae and Paniceae of the family Poaceae. The gametophytic chromosome number in these species range from $n=7$ to 36 . These taxa exist in 33 cytotypes of which $73 \%$ are polyploids and $27 \%$ diploids. Cytology of Calamagrostis stoliczkai and Polypogon viridis has been studied for the first time. New chromosome counts have been recorded in Agrostis munroana, Digitaria cruciata and Phleum himalaicum.

Two base numbers i.e. $x=7$ and 9 have been observed in the 33 taxa studied. The taxa belonging to the tribes Agrostideae and Festuceae have the same base number $(x=7)$ while as plants of the tribe Paniceae have base number $x=9$. While meiosis is normal in all the diploids and 18 polyploid taxa, in 6 polyploid species meiosis is abnormal characterized by the presence of quadrivalents besides bivalents at diplotene and metaphase-I stages indicating towards their segmental allopolyploid nature. In tetraploid Pennisetum orientale associations involving upto five chromosomes are observed which point towards the presence of interchanges superimposed on polyploidy.

\section{Acknowledgements}

The help rendered by the Director, Royal Botanic Gradens, Kew, UK in the identification of the plants is thankfully acknowledged. Thanks are also due to UGC, New Delhi for the financial support. One of us (KKK) also wish to extend his thanks to Mr. Rajesh Kaul for the help provided during the field work.

\section{References}

Bir, S. S. and Sahni, M. 1987. Chromosomal and morphological variation in grasses of Punjab. Proc. Ist. All India Conf. on Cytol and Genet. Bangalore. Abs. (17).

-, -, Kanta, S. and Gill, B. S. 1987. Cytological investigations on some grasses from Punjab plain north India. J. Cytol. and Genet. 22: 15-20

Bor, N. 1969. The grasses of Burma, Ceylon, India and Pakistan, Vol. 1: Pergamon press, Oxford London. Brown, W. V. 1948. A cytological study in the Gramineae. Amer. J. Bot. 35: 382-396.

Carnahan, H. L. and Hill, H. D. 1961. Cytology and genetics of forage grasses. Bot. Rev. 27: 1-162.

Chen, C. C. and Hsu, C. C. 1961. Cytological studies on Taiwan grasses I. Tribe Paniceae. Bot. Bull Acad. Sin. Ser. 2, 2: 101-110.

Darlington, C. D. and Wylie, A. P. 1955. Chromosome atlas of flowering plants. London George Allen and Unwin Ltd.

De Wet, J. M. J. 1954. The genus Danthonia in grass phylogeny. Amer. J. Bot. 41: 204-211

Fedorov, An (ed.) 1969. Chromosome numbers of flowering plants Komarov Botanical Institute. USSR.

Giles, A. and Randolph, L. F. 1951. Reduction of quadrivalent frequency in an autotetraploid maize during a period of 10 years. Amer. J. Bot. 38: 12-17.

Godin, E. D. and Stack, S. M. 1975. Heterochromatic connectives between the chromosomes of Secale cereale. Can. J. Cytol. 17: 269-273.

Gohil, R. N. 1979. Structural heterozygosity in tetraploid Allium platyspathum. Bot. Notiser 132: 325-328.

- and Koul, K. K. 1988a. Reduction division in the hexaploid Agrostis filipes Hook. f. Cytologia 53: 287290. 
- and - 1988b. Cytological studies on Kashmir grasses. IV. Morphological and chromosomal polymorphism in Paspalum distichum L. Nucleus 31: 107-112.

- and Raina, R. 1987. Polyploidy accompanied by structural alterations in the evolution of Hesperis matronalis L. Cytologia 52: 223-228.

Gupta, P. K. 1963. Meiotic studies in some members of the tribe Paniceae. Curr. Sci. 32: 180-181.

Katayama, T. and Ikeda, H. 1975. Cytogenetical studies on Paspalum distichum L. Cytologia 40: 759-764.

Khosla, P. K. and Sharma, M. L. 1973. Cytological studies on some species of Setaria. Nucleus 16: 35-41.

Klášterská, I. 1978. Structure of eukaryotic chromosomes. The differences between mammalian (mouse), grasshopper (Stethophyma) and plant (Rosa) chromosomes as revealed at the diffuse stage of meiosis. Hereditas 88: 243-253.

- and Ramel, C. 1979. The hypotonic pretreatment in mammalian cytology; its function and effect on the aspect of meiotic chromosomes. Hereditas 90: 21-29.

Koul, A. K. and Gohil, R. N. 1971. Further studies on natural triploidy in viviparous onion. Cytologia 36: 253-261.

Koul, K. K. 1990. Cytomixis in pollen mother cells of Alopecurus arundinaceus Poir. Cytologia 55: 169-173.

- and Gohil, R. N. 1989. Cytological studies on some Kashmir grasses. III. Pennisetum orientale L. C. Rich. J. Cytol. and Genet. 24: 23-29.

- and - 1990. Cytological studies on some Kashmir grasses VI. Cytomorphological polymorphism in Alopecurus aequalis Sobol. Cytologia 55: 217-223.

Mehra, P. N., Khosla, P. K., Kohli, B. L. and Koonar, J. S. 1968. Cytological studies in the North Indian grasses; Part I, Rex. Bull. Panjab Univ. 19, Parts I-II; 157-230.

- and Remanandan, P. 1973a. Cytological Investigation on W. Himalayan Pooideae. Cytologia 38: 237258.

- and - 1973b. Cytological Investigations on W. Himalayan Panicoideae. Cytologia 38: 259-270.

- and Sharma, M. L. 1975a. Cytological studies in some central and Eastern Himalayan grasses. II. The Paniceae. Cytologia, 40: 75-89.

- and - 1975b. Cytological studies in some Central and Eastern Himalayan grasses. III. The Agrostideae, Aveneae, Brachypodieae, Bromeae, Festudeae, Phalarideae and Triticeae. Cytologia 40: 441-452.

— and - 1977. Cytological studies on some grasses of Kashmir. Cytologia 42: 111-113.

- and Sunder, S. 1970. Cytological studies in North Indian grasses. Part II Res. Bull. Panjab Univ. 20, Parts-III-IV: 503-539.

McGill, M., Pathak, S. and Hsu, I. C. 1974. Effect of Ethidium bromide on mitosis and chromosomes: a possible material basis for chromosome stickiness. Chromosoma 47: 157-167.

Müntzing, A. and Prakken, R. 1940. The mode of chromosome pairing in Phleum twins with 63 chromosomes and its cytogenetic consequences. Hereditas 26: 463-501.

Narayan, K. N. 1962. Apomixis in some species of Pennisetum and in Panicum antidotale. In: Plant embryology. A symposium CSIR. New Delhi: 55-61.

Nath, J., Swaminathan, M. S. and Mehra, K. L. 1970. Cytological studies in tribe Paniceae (Gramineae). Cytologia 35: 111-131.

Pantulu, J. V. and Rao, K. M. 1982. Cytogenetics of pearl millet. Theor. Appl. Genet. 61: 1-17.

Patil, B. D., Hardas, N. W., O'connor, K. F. and Vohra, S. K. 1962. Polyploidy in Pennisetum orientale. Curr. Sci. 31: 161-162.

Rao, T. N. V. R. 1962. Chromosome number of some Indian grasses. Curr. Sci. 31: 476-477.

Riley, R. L. and Chapman, V. 1958. Genetic control of cytologically diploid behaviour of hexaploid wheat. Nature 182: 713-715.

Sears, E. R. and Okamoto, M. 1958. Intergenomic chromosome relationship in hexaploid wheat. Proc. 10th Int. Congr. Genet. 2: 258-259.

Sharma, A. K. and De, D. N. 1956. Cytology of some of the millets. Caryologia 8: 294-308.

Sharma, M. L. 1979. Some considerations on the phylogeny and chromosome evolution in grasses. Cytologia 44: 679-685.

- and Sharma, K. 1979. Cytological studies in the North Indian grasses. Cytologia 44: 861-872.

Singh, F., Ved Brat, S. and Khoshoo, T. N. 1967. Natural triploidy in viviparous onions. Cytologia 32: 403-407.

Singh, R. V. and Gupta, P. K. 1977. Cytological studies in the genus Setaria (Gramineae). Cytologia 42: 483-493.

Stack, S. M. and Clarke, C. R. 1973. Differential giemsa staining of telomeres of Allium cepa chromosomes, observa tions related to chromosome pairing. Can. J. Genet. Cytol. 15: 619-624.

Stebbins, G. L. 1956. Cytogenetics and evolution of the grass family. Amer. J. Bot. 43: 890-905. 
- 1971. Chromosomal Evolution in Higher Plants. Edward Arnold Publ. London.

Swaminathan, M.S. and Nath, J. 1956. Two new basic chromosome numbers in the genus Pennisetum. Nature 178: 1241-1242.

- and Sulbha, K. 1959. Multivalent frequency and seed fertility in raw and evolved tetraploids of Brassica campestris var. toria. $z$. vereb. 90: 358-392.

Tsvelev, N. N. and Zhukova, P. G. 1974. The minimal basic chromosome number in the family poaceae. Bot. Zh. (Leningr.), 59(2): 265-269.

Wanscher, J. H. 1934. The basic chromosome numbers of the higher plants. New phytol. 33: 101-126.

Yunis, J. J. and Yasmineh, W. G. 1971. Heterochromatin, Satellite DNA, and Cell Function. Nature (London), New Biol. 233: 268-271.

- and - 1972. Model for mammalian constitutive heterochromatin, Adv. Cell. Mol. Biol 2: 1-46. 